\title{
Influence of Pasteurization and Storage on Dynamic In Vitro Gastric Digestion of Milk Proteins: Quantitative Insights Based on Peptidomics
}

\author{
Xing $\mathrm{Li}^{1}{ }^{1}$, Yuxiang Gu ${ }^{1}$, Shudong $\mathrm{He}^{2}{ }^{2}$, Olayemi Eyituoyo Dudu ${ }^{1}$, Qiming $\mathrm{Li}^{3,4}$, \\ Haiyan Liu ${ }^{1,3,4}$ and Ying $\mathrm{Ma}^{1, *}$ \\ 1 School of Chemistry and Chemical Engineering, Harbin Institute of Technology, 92 West Dazhi Street, \\ Harbin 150001, China; leestar1104@163.com (X.L.); Yuxiang.Gu@outlook.com (Y.G.); \\ duduolayemi@live.com (O.E.D.); liuhy1@newhope.cn (H.L.) \\ 2 School of Food and Biological Engineering, Engineering Research Center of Bio-Process of Ministry of \\ Education, Hefei University of Technology, Hefei 230009, China; shudong.he@hfut.edu.cn \\ 3 New Hope Dairy Co, Ltd., Chengdu 610063, China; qm258@126.com \\ 4 Dairy Nutrition and Function, Key Laboratory of Sichuan Province, Chengdu 610000, China \\ * Correspondence: maying@hit.edu.cn; Tel./Fax: +86-0451-86282906
}

Received: 23 June 2020; Accepted: 23 July 2020; Published: 25 July 2020

\begin{abstract}
It is important to evaluate the nutritional quality of milk during the shelf-life, especially during home storage, from a consumer viewpoint. In this study, we investigated the impact of pasteurization $\left(85^{\circ} \mathrm{C} / 15 \mathrm{~s}\right.$ ) and subsequent storage (at $4{ }^{\circ} \mathrm{C}$ for 7 days) on the coagulation behavior of milk and protein digestibility in a dynamic in vitro gastric digestion test. A high level of hydration in curd formed in pasteurized milk upon 7-day cold storage compared to raw and pasteurized milk, indicating fast pepsin diffusion in the interior of curds, increasing the hydrolysis rate. The digesta collected at various time points throughout the gastric digestion were studied using $o$-phthaldialdehyde (OPA), sodium dodecyl sulfate polyacrylamide gel electrophoresis (SDS-PAGE), liquid chromatography tandem mass spectrometry (LC-MS/MS), and amino acid analysis. These results showed that milk proteins were hydrolyzed quickly upon a long period of cold storage. Additionally, qualitative and quantitative results obtained using LC-MS/MS exhibited significant differences between samples, especially in pasteurized milk upon cold storage. Processing and storage played a decisive role in bioactive peptide generation. Such knowledge could provide insights into and directions for the storage of pasteurized milk for further clinical studies on protein bioavailability and the generation of bioactive peptides for desired health outcomes.
\end{abstract}

Keywords: milk protein; dynamic in vitro digestion; peptidomics; pasteurization milk; storage

\section{Introduction}

Milk proteins, as an important aspect of dietary proteins for humans, have a good nutritional value: They have a high content of several essential amino acids and good digestibility [1]. Moreover, milk proteins have recently attracted an increasing amount of attention, since they contain bioactive peptides which can be released during gastrointestinal digestion [2]. Caseins, representing $80 \%$ of milk proteins, form a highly hydrated micellar assembly of several thousand individual casein molecules, known as casein micelles [3]. $\beta$-lactoglobulin $(\beta-\mathrm{Lg})$, a major whey protein, has been extensively studied because of its thermal instability. Heat treatment above $60^{\circ} \mathrm{C}$ leads to $\beta$-Lg denaturation, aggregation, and the association of denatured $\beta$-Lg with casein micelles through interactions with $\kappa$-casein [4]. These structural changes at the molecular level can lead to changes in the physicochemical properties of milk (viscosity, surface hydrophobicity, rheological property, etc.) [5-7]. Moreover, these 
changes might have both desirable and undesirable effects on the cleavage sites of enzymes, resulting in the modification of protein digestibility.

Milk proteins show complex digestive kinetics during gastric digestion. Casein micelles can precipitate and coagulate curds during gastric digestion. A reduction of the pepsin diffusivity inside curds compared to diffusion in solution can significantly decrease the rate of gastric emptying [6]. Whey proteins, which are soluble in serum, can remain mostly intact during gastric digestion and quickly enter the duodenum. However, heat treatment $>80^{\circ} \mathrm{C}$ induces the unfolding of $\beta$ - $\mathrm{Lg}$, which exposes the peptic cleavage sites and thus increases their susceptibility to hydrolysis [8]. The digestibility of casein is also altered upon heat treatment $[9,10]$. The impact of heat treatment on changes in the cleavage sites of milk proteins using mass spectrometry have attracted extensive attention [10-12]. The results have shown that the effect of heat treatment can notably change the peptides released during gastric digestion. Regrettably, no quantitative data have been obtained because of limited mass spectrometry technology, so there is no clear guidance for evaluating the differences in cleavage sites. Ye, Cui (9) found that the curds formed in heated milk during gastric digestion can be hydrolyzed quickly compared to raw milk using sodium dodecyl sulfate polyacrylamide gel electrophoresis (SDS-PAGE) based on a dynamic gastric simulator.

As a major commercial dairy product, pasteurized milk is consumed globally in large quantities. Pasteurized milk is not sterile. Therefore, it needs to be stored at $4-6{ }^{\circ} \mathrm{C}$ and has a shelf-life of approximately 7 days from a microbiological safety point of view [13]. Some association and dissociation of milk proteins occur in pasteurized milk during storage, despite the short shelf-life and low storage temperature $[14,15]$. Modification of the surface hydrophobicity of proteins and a marked increase of the casein micelle size were observed in pasteurized milk upon cold storage [15]. These results showed that protein interactions still occurred in a prolonged storage time, which might influence the milk protein bioavailability.

Little is known about the changes in milk protein digestibility that occur in pasteurized milk during storage. From a nutritional point of view, the effects of the storage time on milk protein digestibility could influence the nutritional quality of the product. In this study, we investigated the impact of storage on the hydrolysis kinetics of proteins in pasteurized milk, with a particular focus on the evolution of the peptidome generated during gastric digestion under these conditions. The recent advent of highly sensitive mass spectrometry (Q Exactive mass spectrometry (ThermoFisher Scientific, San Jose, CA, USA) coupled with Maxquant software version 1.5.0.0) can provide site-specific identification and semi-quantification. The identification of these differences will provide a better understanding of the nutritional quality and deliver better benefits of liquid milk products.

\section{Materials and Methods}

\subsection{Materials}

Fresh raw milk (RM) and commercial skimmed pasteurized milk were obtained from a local dairy company (Harbin, Heilongjiang, China). Skimmed pasteurized milk was subjected to an indirect injection at $85^{\circ} \mathrm{C}$ for $15 \mathrm{~s}$ in a commercial-scale pasteurized plant (Xuhui Co., Ltd., Shanghai, China). The defatted process was conducted using a milk defatting centrifugal cream separator (Xuhui Co., Ltd., Shanghai, China) prior to pasteurization. The batch size was 10 tons and the volumetric flow rate was 5 tons/h. Pasteurized milk was stored at $4{ }^{\circ} \mathrm{C}$ for up to 7 days. Samples were taken for analysis at day 0,3 , and 7 (PM0d, PM3d, and PM7d, respectively).

Pepsin from porcine gastric mucosa (P7000, $825 \mathrm{U} / \mathrm{mg}$ ) was purchased from Sigma-Aldrich Corp. (St. Louis, MO, USA). Coomassie Brilliant Blue R-250 was obtained from Bio-Rad Laboratories, Inc. (Hercules, CA, USA). Water was purified by treatment with a Millipore purification system $(>18.3 \mathrm{M} \Omega \cdot \mathrm{cm}$, Millipore Corp., Bedford, MA, USA) and used for all experiments. All of the other chemicals obtained from Solarbio Co., Ltd. (Beijing, China) were of analytical grade, unless otherwise specified. 


\subsection{Dynamic In Vitro Gastric Digestion}

The dynamic gastric digestion model used for in vitro gastric digestion was developed according to the human gastric simulator (HGS), with some modification [16]. Simulated gastric fluid (SGF) stock electrolyte solution was adjusted to the recommended levels, as described in the standardized consensus [17]. The dynamic gastric digestion model (Figure 1) mainly consisted of a digestion beaker, a temperature-controlled incubator (HZS-HA, HDL Apparatus Institute, Changzhou, China), a spherical Teflon probe of a $30 \mathrm{~mm}$ diameter attached to the stepper motor via a thin Teflon rod of a $5 \mathrm{~mm}$ diameter, two injection pumps (F01A STP, Kamoer pump Co., Ltd., Shanghai, China), and an emptying pump (NKCP, Kamoer pump Co., Ltd., Shanghai, China). The main digestion beaker had a diameter of $74 \mathrm{~mm}$, a depth of $90 \mathrm{~mm}$, and a volume of $350 \mathrm{~mL}$. A simple mechanical movement was able to simulate the peristaltic contractions of the stomach wall according to a published study, with modification [18]. The probe could be moved up and down under the control of the stepper motor at $9 \mathrm{~mm} / \mathrm{s}$ to simulate the actual stomach contraction frequency of 3 cycles per minute [19]. The maximum antral force in this model was calculated using the mathematical modeling software COMSOL Multiphysics (COMSOL, Inc., Version 5.5, Stockholm, Sweden) and the maximum antral force was $23,000 \mathrm{~N} / \mathrm{m}^{2}$, which was in a reasonable range of that presented in a human stomach ranging from 5134 to $67,292 \mathrm{~N} / \mathrm{m}^{2}$ [16]. A thin polyester mesh bag (pore size $1 \mathrm{~mm}$ ) was placed inside the digestion beaker to simulate a sieving effect of the pylorus, which only allowed particles with a size $<1 \mathrm{~mm}$ to pass through to the duodenum [20]. The temperature of the beaker was maintained at $37^{\circ} \mathrm{C}$ using the temperature-controlled incubator.

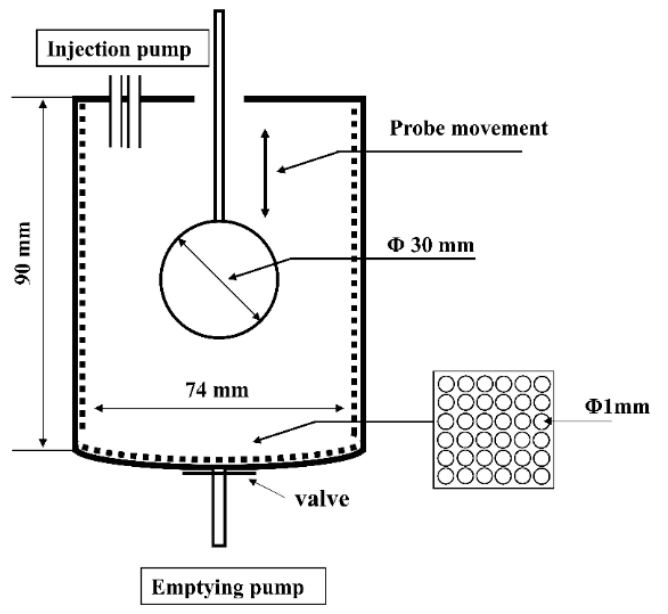

Figure 1. A schematic illustration of the dynamic in vitro gastric digestion model.

The $\mathrm{pH}$ of the SGF was adjusted to 1.5 using $1 \mathrm{M} \mathrm{HCl}$. Another simulated digestive fluid containing $4.8 \mathrm{~g} / \mathrm{L}$ of pepsin and $0.15 \mathrm{mM}$ of $\mathrm{CaCl}_{2}$ was diluted to the correct electrolyte concentration with water. The dosage of the SGF and pepsin solution was 80 and $20 \mathrm{~mL}$, respectively, as described in our previous study [21]. They were then added at a rate of $2.5 \mathrm{~mL} / \mathrm{min}$ (controlled by a rate of $2.0 \mathrm{~mL} / \mathrm{min}$ of the SGF and a rate of $0.5 \mathrm{~mL} / \mathrm{min}$ of the pepsin solution addition by using two injection pumps, respectively). All of the solutions were warmed at $37^{\circ} \mathrm{C}$. The milk sample $(100 \mathrm{~mL})$ was loaded into the digestion beaker and warmed at $37^{\circ} \mathrm{C}$ for $2 \mathrm{~min}$ to mimic oral prewarming. The digesta began to be emptied out from $30 \mathrm{~min}$ and the gastric emptying rate was $3.0 \mathrm{~mL} / \mathrm{min}$. The gastric digestion lasted $2 \mathrm{~h}$. Samples of the digesta were collected at 2, 5, 10, 20, 30, 60, 90, and $120 \mathrm{~min}$ of digestion for an analysis of breakdown products. Samples of the digesta were adjusted to 6.8 using dilute $\mathrm{NaOH}$ to terminate the enzymatic reaction. Samples at each time point were prepared separately, and all experiments were conducted in triplicate. 


\section{3. $\mathrm{pH}$ Measurement}

The initial $\mathrm{pH}$ was defined as the $\mathrm{pH}$ of the milk. The $\mathrm{pH}$ at different digestion time points was defined as the $\mathrm{pH}$ of the emptied digesta according to the previous method [20].

\subsection{Weight of Curds}

The curds obtained from the raw milk and pasteurized milk after digestion at different time points were removed and weighted immediately [9]. The weights of dried curds were determined after being dried at $105^{\circ} \mathrm{C}$ for $12 \mathrm{~h}$ in a vacuum oven $[9,20]$.

\subsection{Degree of Hydrolysis}

The extent of protein hydrolysis was determined using the standardized $o$-phthaldialdehyde (OPA) spectrophotometric assay [22]. Briefly, $0.2 \mathrm{~mL}$ of sample was added to $1.5 \mathrm{~mL}$ of OPA reagent, mixed well, and incubated at room temperature for $2 \mathrm{~min}$. The optimal density at $340 \mathrm{~nm}$ was measured using a UV-2100 spectrophotometer (Beifen-Ruili Analytical Instrument Co., Ltd., Beijing, China). The number of amino groups was determined from an L-leucine $(0-2 \mathrm{mg} / \mathrm{mL})$ standard curve and the proteolytic activity was calculated according to the equation described in a previous report [22]. Each assay was done in triplicate for all samples.

\subsection{Sodium Dodecyl Sulfate Polyacrylamide Gel Electrophoresis (SDS-PAGE)}

SDS-PAGE was performed as described by Ji, $\mathrm{Li}$ (23) using a 15\% resolving gel and $4 \%$ stacking gel. All samples were centrifuged at $12,000 \times g$ for $10 \mathrm{~min}$ and supernatant fractions were mixed with SDS-PAGE buffer at a volume ratio of 1:1. The gel electrophoresis was run at $125 \mathrm{~V}$ for $1.5 \mathrm{~h}$. The gels were imaged and quantified using the Molecular Imager Gel Doc XR system (Bio-Rad Laboratories, Hercules, CA, USA) and Quantity One 1-D analysis software (Bio-Rad Laboratories, Hercules, CA, USA).

\subsection{Liquid Chromatography Tandem Mass Spectrometry (LC-MS/MS)}

The digesta were filtered through 3000 molecular weight cut-off centrifugal filters (Amicon ${ }^{\circledR}$ Ultra-4, Merck Millipore, Billerica, MA, USA) and equalized by adding an appropriate volume of water prior to running LC-MS. The Thermo Scientific Q Exactive mass spectrometer equipped with an UHPLC system (Easy-nLC ${ }^{\mathrm{TM}}$ 1000, Thermo Fisher Scientific, San Jose, CA, USA) was applied for liquid chromatography tandem mass spectrometry (LC-MS/MS) analysis. A total of $10 \mu \mathrm{L}$ of sample was loaded on a reverse phase trap column (Thermo Scientific Acclaim PepMap100, $200 \mathrm{~mm} \times 100 \mu \mathrm{m}$, nanoViper C18, San Jose, CA, USA) connected to the C18-reversed analytical column (Thermo Scientific Easy Column, $3 \mu \mathrm{m}, 100 \mathrm{~mm} \times 75 \mu \mathrm{m}$, San Jose, CA, USA). The elution of peptides was carried out at a flow rate of $300 \mathrm{~nL} / \mathrm{min}$ controlled by IntelliFlow technology (Thermo Fisher Scientific, San Jose, CA, USA), with solvent A (water containing $0.1 \%$ formic acid) and solvent B ( $84 \%$ acetonitrile containing $0.1 \%$ formic acid) as eluents. The gradient elution program was as follows: linear gradient from 0 to $35 \%$ B for $50 \mathrm{~min}$, from 35 to $100 \%$ B for $5 \mathrm{~min}$, and held at 100\% B for $5 \mathrm{~min}$.

The mass spectrometer was operated in positive ion mode. A spray voltage of $2.2 \mathrm{kV}$ was used with a transfer capillary temperature of $200{ }^{\circ} \mathrm{C}$. Mass Spectrometry (MS) data were acquired using a data-dependent top 10 method dynamically choosing the most abundant precursor ions from the survey scan (300-1800 m/z) for high-energy collisional dissociation (HCD) fragmentation [23]. An automatic gain control (AGC) target was set to $3 \mathrm{e} 6$, and the maximum injection time was set to $10 \mathrm{~ms}$. The dynamic exclusion duration was $40.0 \mathrm{~s}$. Survey scans were acquired at a resolution of 70,000 at $\mathrm{m} / \mathrm{z} 200$, the resolution for HCD spectra was set to 17,500 at $\mathrm{m} / \mathrm{z} 200$, and the isolation width was $2 \mathrm{~m} / \mathrm{z}$. The normalized collision energy was $30 \mathrm{eV}$ and the underfill ratio, which specifies the minimum percentage of the target value likely to be reached at the maximum fill time, was defined as $0.1 \%$. The instrument was run with peptide recognition mode enabled. 


\subsection{Sequence Database Searching and Data Analysis}

MS/MS spectra were searched using MaxQuant software version 1.3.0.5 (Max Planck Institute of Biochemistry, Martinsried, Germany) against the UniProt Bos Taurus database and the decoy database. For protein identification, the following parameters were set: Main search $=6 \mathrm{ppm}$, first search $=20 \mathrm{ppm}$, MS $/ \mathrm{MS}$ tolerance $=20 \mathrm{ppm}$, and max missed cleavage $=2$. The fixed modification was Carbamidomethyl (C) and the variable modifications were the oxidation (M), acetyl (protein $\mathrm{N}$-term), protein false discovery rate $(F D R) \leq 0.01$, and peptide $F D R \leq 0.01$.

Peptigram, a web-based visualization tool for peptidomics data, was used to visualize the peptide distributions in different samples. It is freely available for academic use at http://bioware.ucd.ie/ peptigram [24]. To investigate the differences in the bioactive peptides between different samples, the BIOPEP database (http://www.uwm.edu.pl/biochemia/index.php/en/biopep) was used to match peptide sequences.

\subsection{Amino Acid Analysis}

The levels of free amino acids released from samples were determined by ion chromatography, according to a previous report [25]. Briefly, $1 \mathrm{~mL}$ samples were mixed with $50 \mathrm{mg}$ of sulfosalicylic acid and incubated for $1 \mathrm{~h}$ at $4{ }^{\circ} \mathrm{C}$. The mixtures were centrifuged at $5000 \times \mathrm{g}$ for $15 \mathrm{~min}$ at $4{ }^{\circ} \mathrm{C}$ and the supernatants were filtered through a $0.45 \mu \mathrm{m}$ pore-size membrane (A-FIT Biosciences Ltd., Beijing, China). The filtrate was diluted two times with a $0.2 \mathrm{M}$ lithium citrate buffer ( $\mathrm{pH}$ 2.2). The amino acid analysis was then carried out by cation exchange chromatography on an automatic amino acid analyzer (Biochrom Ltd., Cambridge, Cambourne, UK).

\subsection{Statistical Analysis}

All samples were prepared in three independent milk aliquots and each was analyzed in triplicate. Data were analyzed by an analysis of variance (ANOVA) and the differences between means were analyzed by the Duncan test. The results were considered significant at $p<0.05$.

\section{Results and Discussion}

\subsection{Change in $\mathrm{pH}$}

The $\mathrm{pH}$ of the samples gradually decreased along with an increase in the digestion time (Figure 2A). There was no significant difference in the $\mathrm{pH}$ profiles between pasteurized milk and raw milk, but a slower decrease in the $\mathrm{pH}$ was observed in pasteurized milk during storage. The differences in the $\mathrm{pH}$ profiles were ascribed to the different structures of the curds that formed in milk samples during digestion, which could alter the buffer capacity of milk [11,20]. A slow decrease in pH observed in pasteurized milk upon 7 days of storage indicated that a curd which could exert a greater buffer capacity was formed and slowed down the decrease in $\mathrm{pH}$. 

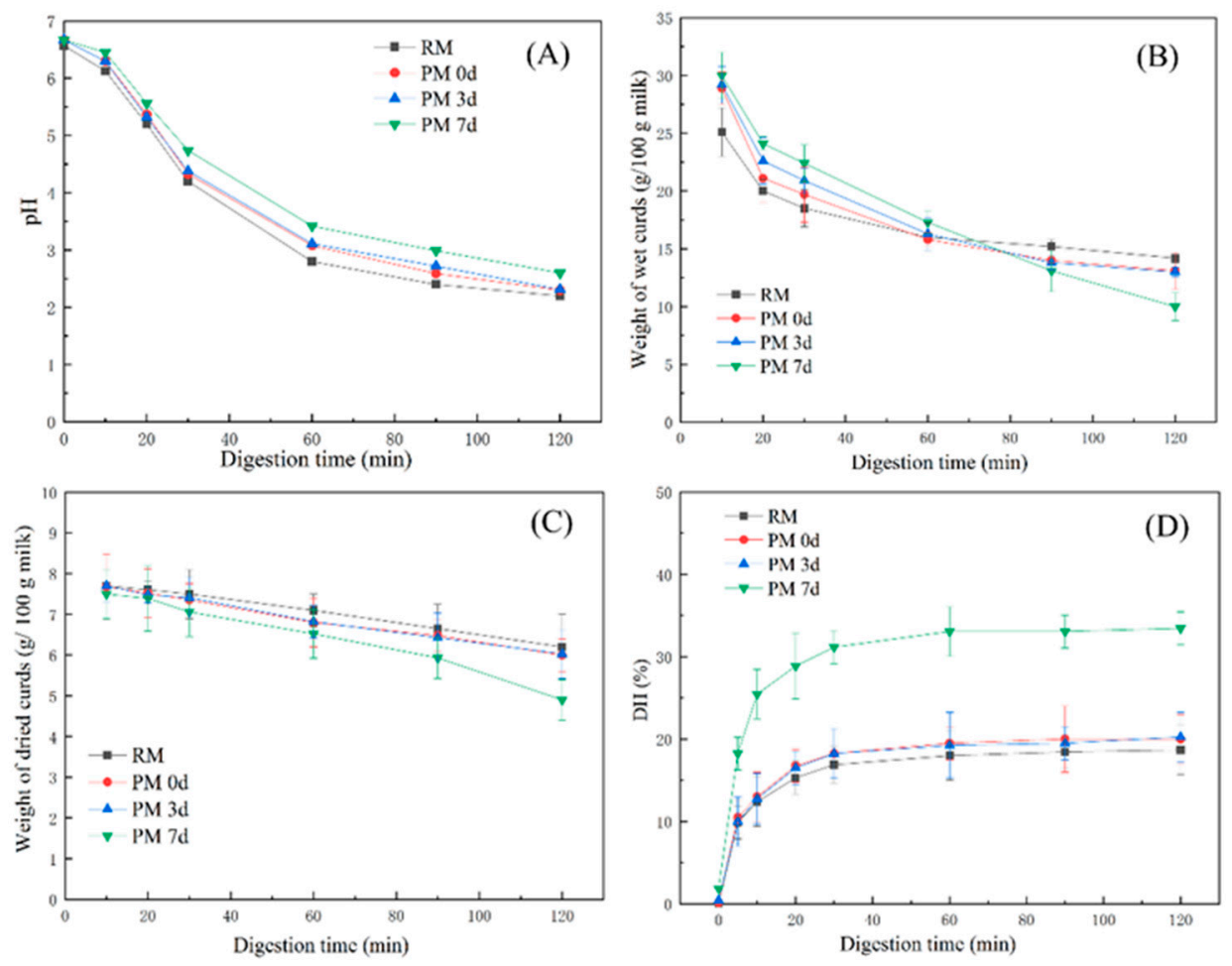

Figure 2. Changes in the $\mathrm{pH}(\mathbf{A})$, weight of wet curds ( $\mathrm{g} / 100 \mathrm{~g}$ milk) (B), weight of dried curds (g/100 g milk) (C), and degree of protein hydrolysis (D) from raw milk (RM), pasteurized milk (PM0d), pasteurized milk upon 3 days of storage (PM3d), and pasteurized milk upon 7 days of storage (PM7d) during in vitro gastric digestion. Error bars represent the standard deviation of three independent samples and each was measured in triplicate.

\subsection{Coagulation Behavior of Milk}

The weights of the curds decreased gradually with the digestion time up to 120 min (Figure 2B). During the early digestion period (at $10 \mathrm{~min}$ ), the weights of the curds formed from pasteurized milk were greater than those in raw milk $(p<0.05)$. However, after 90 min of digestion, the curd weights from pasteurized milk, especially upon 7 days of cold storage, were lower than those from raw milk. Figure $2 \mathrm{C}$ shows that all milk samples had similar weight profiles of dried curds, except for the weight from pasteurized milk stored at 7 days, which was lower than other samples at $120 \mathrm{~min}$ of gastric digestion $(p<0.05)$.

The curds were visible at $10 \mathrm{~min}$ of digestion where the $\mathrm{pH}$ was above 6.0 , which was consistent with previous reports on whole and skimmed milk $[11,20]$. This could be attributed to the destabilization of casein micelles caused by the proteolytic activity of pepsin. Casein micelles are stabilized by steric repulsion generated by the polyelectrolyte layer of $k$-casein [5]. $k$-casein has been shown to be hydrolyzed faster than other caseins by pepsin at $\mathrm{pH} 6.0$ [26], which could induce sterical destabilization of the micelles and cause them to coagulate. At $10 \mathrm{~min}$ of gastric digestion, the weights of wet curds in pasteurized milk were higher than those in raw milk, while the weights of dry curd were similar between raw and pasteurized milk. This result indicated higher hydration of the curd formed in pasteurized milk, which could easily provide cleavage sites for pepsin and increase the digestion rate. The quick hydrolysis of curds observed in milk upon 7-day storage during gastric digestion could be due to the highest water-holding capacity of curds, which could be more susceptible to hydrolysis by pepsin. 


\subsection{The Degree of Protein Hydrolysis}

Figure 2D shows the hydrolysis degree of milk proteins in samples. All of the samples were quickly hydrolyzed in the first $30 \mathrm{~min}$ of digestion and then remained constant after $60 \mathrm{~min}$. At the end of the gastric digestion (120 min), a higher hydrolysis degree (33\%) was observed from pasteurized milk upon 7 days of storage compared to other samples (19-20\%). Milk proteins that existed in the interior of the curd could be hardly hydrolyzed by pepsin. The high level of hydration in the curd formed in pasteurized milk upon 7-day storage could provide faster pepsin diffusion in the curd, leading to a higher hydrolysis degree in the PM7d sample.

\subsection{Hydrolysis of Protein in Digesta}

To investigate the difference in the protein hydrolysis kinetics between the raw milk and pasteurized milk upon different storage times, the SDS-PAGE profiles of samples in the digesta at different time points of digestion are shown in Figure 3. In general, caseins were digested much faster than whey proteins under the in vitro gastric condition. In the case of raw milk (Figure 3A), caseins were rapidly hydrolyzed within the first $2 \mathrm{~min}$ of digestion and no obvious intact caseins were visible after $20 \mathrm{~min}$. In comparison, the digestion of major whey protein $\beta$ - $\mathrm{Lg}$ was much slower, as indicated by the small change in the intensity of the $\beta$ - $\mathrm{Lg}$ band during the $120 \mathrm{~min}$ gastric digestion. No significant changes in the intensity of the casein bands in pasteurized milk (PM0d) were observed compared to raw milk (Figure 3B). The digestion of $\beta$ - $\mathrm{Lg}$ was slightly increased in the pasteurized milk compared to raw milk during the initial $2 \mathrm{~min}$ and remained constant over $120 \mathrm{~min}$ of digestion. During the subsequent storage of pasteurized milk, the SDS-PAGE profiles of proteins were altered. The contents of caseins and $\beta$-Lg in stored pasteurized milk prior to digestion were decreased based on quantitative data, although there were minor changes in PM3d (at time 0 in Figure 3C,D). Moreover, several new intermediate molecular weight bands (19 to $24 \mathrm{kDa}$ ) were visible in stored pasteurized milk prior to digestion, following by gradual degradation over $30 \mathrm{~min}$ of digestion. The changes in the intensities of casein and $\beta$-Lg bands during digestion were not obvious in stored pasteurized milk compared with those in PMOd.

Caseins are susceptible to pepsin hydrolysis. Native $\beta$ - $\mathrm{Lg}$ is more resistant to pepsin hydrolysis because of its structural stability at a low $\mathrm{pH}$ [27-29], as most of the hydrophobic amino acid residues, which are potential cleavage sites for pepsin, are buried inside the $\beta$-barrel and thus not readily accessible [9]. $\beta$ - $\mathrm{Lg}$ is also more sensitive to heat-induced structural unfolding beginning at $80{ }^{\circ} \mathrm{C}$ [29]. The unfolding of $\beta$-Lg provided better excess for pepsin to hydrolyze, leading to a faster digestion rate of $\beta-\operatorname{Lg}$ [7]. The hydrolysis of $\beta-\operatorname{Lg}$ in pasteurized milk was limited, which was due to the low content of denatured $\beta-\mathrm{Lg}$ in pasteurized milk. 

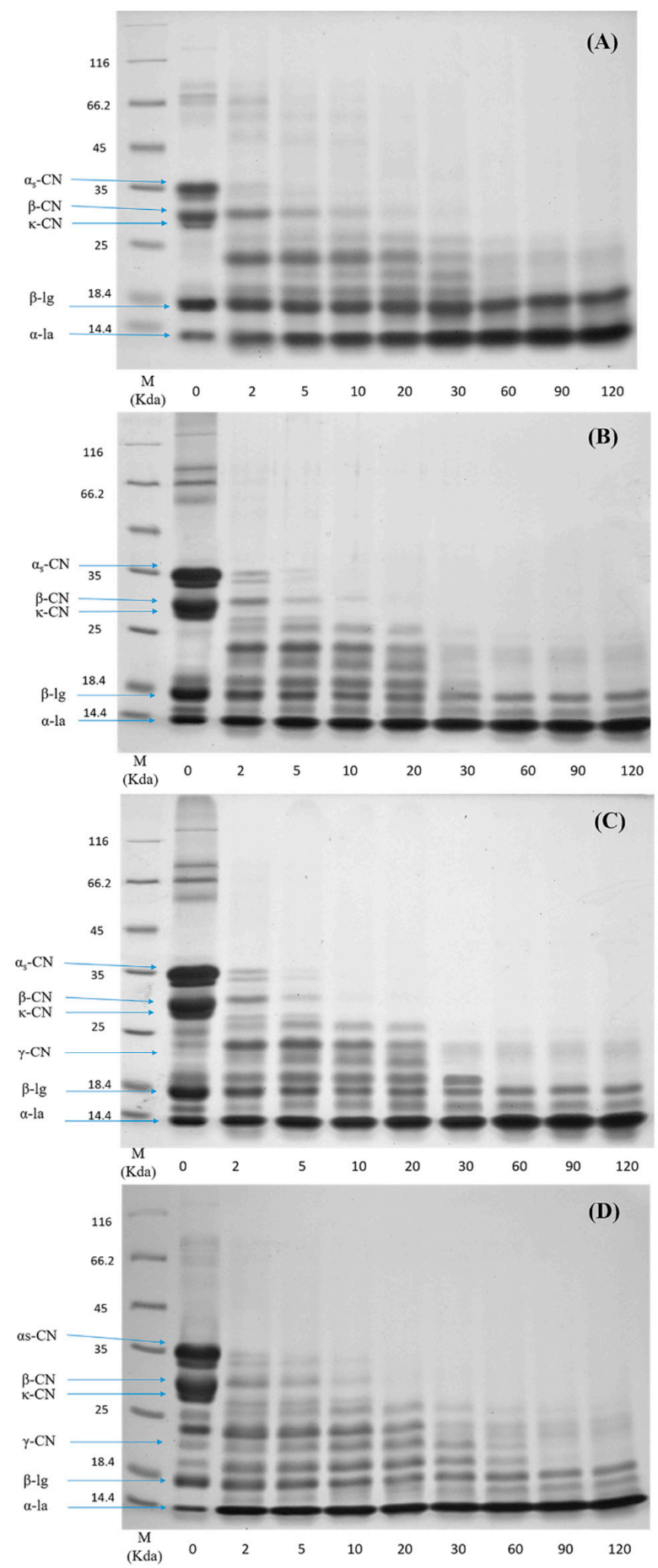

Figure 3. Sodium dodecyl sulfate polyacrylamide gel electrophoresis (SDS-PAGE) profiles of the in vitro gastric digestion of (A) raw milk, (B) pasteurized milk, (C) pasteurized milk upon 3 days of storage, and (D) pasteurized milk upon 7 days of storage. Lane M shows molecular weight markers. The number at the bottom of each lane represents the time of digestion (min).

Relatively low contents of proteins in stored milk indicated that protein hydrolysis occurred in cold storage. This observation was consistent with our previous work, in which the protein content was decreased and non-protein nitrogen was increased during storage [15]. The digestion patterns of caseins and $\beta$-Lg in digesta were similar between PM0d and stored pasteurized milk. The mechanism behind this phenomenon was not clear, and it can probably be attributed to three major reasons. The first 
was that the cold storage promoted a small dissociation of colloidal caseins, especially $\beta-\mathrm{CN}$ [30]. The dissociated caseins that entered the serum could be easily hydrolyzed by pepsin. The second was that the curds in long-period stored milk were hydrolyzed quickly, which might also induce more small curd particles $(<1 \mathrm{~mm})$ peeled off into the digesta during the initial period of digestion. The particle size analysis using the Nano-ZS particle analyzer (Malvern Instruments Ltd., UK) showed a higher proportion of relatively large particles $(>1000 \mathrm{~nm})$ found in stored milk (result not known). These particles might result in an increase of the intact protein contents in digesta using SDS-PAGE analysis. The third was protein interactions and associated molecular modifications occurred and increased during storage, especially in pasteurized milk upon 7 days of storage $[15,17]$, which could change the protein digestibility. For example, glycation and lactosylation could block lysine residues and thereby hinder the access of pepsin to the cleavage sites. Indeed, further work was needed to study the impact of cold storage on the digestibility of the individual milk protein. It was noted that $\gamma-\mathrm{CN}$ (at $\sim 21 \mathrm{kDa}$ ) was observed in pasteurized milk during storage, indicating that $\beta-\mathrm{CN}$ was hydrolyzed in the prolonged storage time. $\gamma-\mathrm{CN}$ was more slowly hydrolyzed compared to other caseins and the band was observed after $30 \mathrm{~min}$ of digestion. Plasmin, a heat-stable proteinase that exists in pasteurized milk during storage, can cleave the plasmin-sensitive bonds in $\beta-\mathrm{CN}$ and lead to the formation of $\gamma-\mathrm{CN}$ [31]. The slow hydrolysis rate of $\gamma-\mathrm{CN}$ might be due to the fact that the structural changes in $\gamma-\mathrm{CN}$ originating from $\beta-\mathrm{CN}$ could hinder the access of pepsin to the cleavage sites. These results indicated that cold storage could change the milk protein digestibility.

\subsection{Peptides Generated upon Cold Storage}

The occurrence of proteolysis in pasteurized milk during a long period of cold storage has been confirmed in our previous study [15]. The generated peptides caused by stored-induced proteolysis prior to digestion are shown in Table 1. To better understand the peptide generation mechanism, the peptides generated prior to digestion are also shown, along with peptide profiles during digestion (Figure 4, Figure 5 and Supplementary Materials Figure S5). All of the peptides originated from $\alpha_{\mathrm{s} 1}-\mathrm{CN}, \alpha_{\mathrm{s} 2}-\mathrm{CN}$, and $\beta-\mathrm{CN}$. No peptide was found in $\mathrm{k}-\mathrm{CN}$ and $\beta-\mathrm{Lg}$. Pasteurization, as a mild thermal processing technique, could induce two peptides $\left(\alpha_{\mathrm{s} 1}-\mathrm{CN}_{200-214}\right.$ and $\left.\beta-\mathrm{CN}_{207-224}\right)$ generated. Proteolysis occurred in stored milk, especially in PM7d, which could change the protein structure and thereby alter the protein digestibility (such as the digestibility of $\gamma-\mathrm{CN}$, which was different from that of $\beta-\mathrm{CN})$. Moreover, the contents of the generated peptides were also altered during gastric digestion. For example, the intensity of peptide $\beta-\mathrm{CN}_{208-221}$ (YQEPVLGPVRGPFP) was similar between PM7d $0 \mathrm{~min}$ and PM7d 10min and its intensity was gradually decreased with an increase in the digestion time. This result indicated that this peptide could not be formed during gastric digestion, whereas it could be further degraded under the action of pepsin.

Table 1. Peptides identified in raw milk (RM), pasteurized milk (PM0d), pasteurized milk upon 3 days of storage (PM3d), and pasteurized milk upon 7 days of storage (PM7d) prior to digestion.

\begin{tabular}{|c|c|c|c|c|c|c|}
\hline Parent Protein & Peptide Sequence & Position & RM & PMOd & PM3d & PM7d \\
\hline \multirow[t]{4}{*}{$\alpha_{\mathrm{s} 1}-\mathrm{CN}$} & RPKHPIKHQGLPQEVLNENLLR & $16-37$ & & & & $\sqrt{ }$ \\
\hline & SDIPNPIGSENSEKTTMPLW & $195-214$ & & & $\sqrt{ }$ & $\sqrt{ }$ \\
\hline & PIGSENSEKTTMPLW & $200-214$ & & $\sqrt{ }$ & $\sqrt{ }$ & $\sqrt{ }$ \\
\hline & SEKTTMPLW & $206-214$ & & & & $\sqrt{ }$ \\
\hline$\alpha_{\mathrm{s} 2}-\mathrm{CN}$ & TKVIPYVRYL & $213-222$ & & & & $\sqrt{ }$ \\
\hline \multirow[t]{6}{*}{$\beta-\mathrm{CN}$} & RELEELNVPGE & $16-26$ & & & $\sqrt{ }$ & $\sqrt{ }$ \\
\hline & HKEMPFPKYPVEPFTESQS & $121-139$ & & & & $\sqrt{ }$ \\
\hline & LYQEPVLGPVRGPFPIIV & $207-224$ & & $\sqrt{ }$ & $\sqrt{ }$ & $\sqrt{ }$ \\
\hline & YQEPVLGPVRGPFP & $208-221$ & & & & $\sqrt{ }$ \\
\hline & YQEPVLGPVRGPFPIIV & $208-224$ & & & $\sqrt{ }$ & $\sqrt{ }$ \\
\hline & PVRGPFPIIV & $215-224$ & & & & $\sqrt{ }$ \\
\hline
\end{tabular}



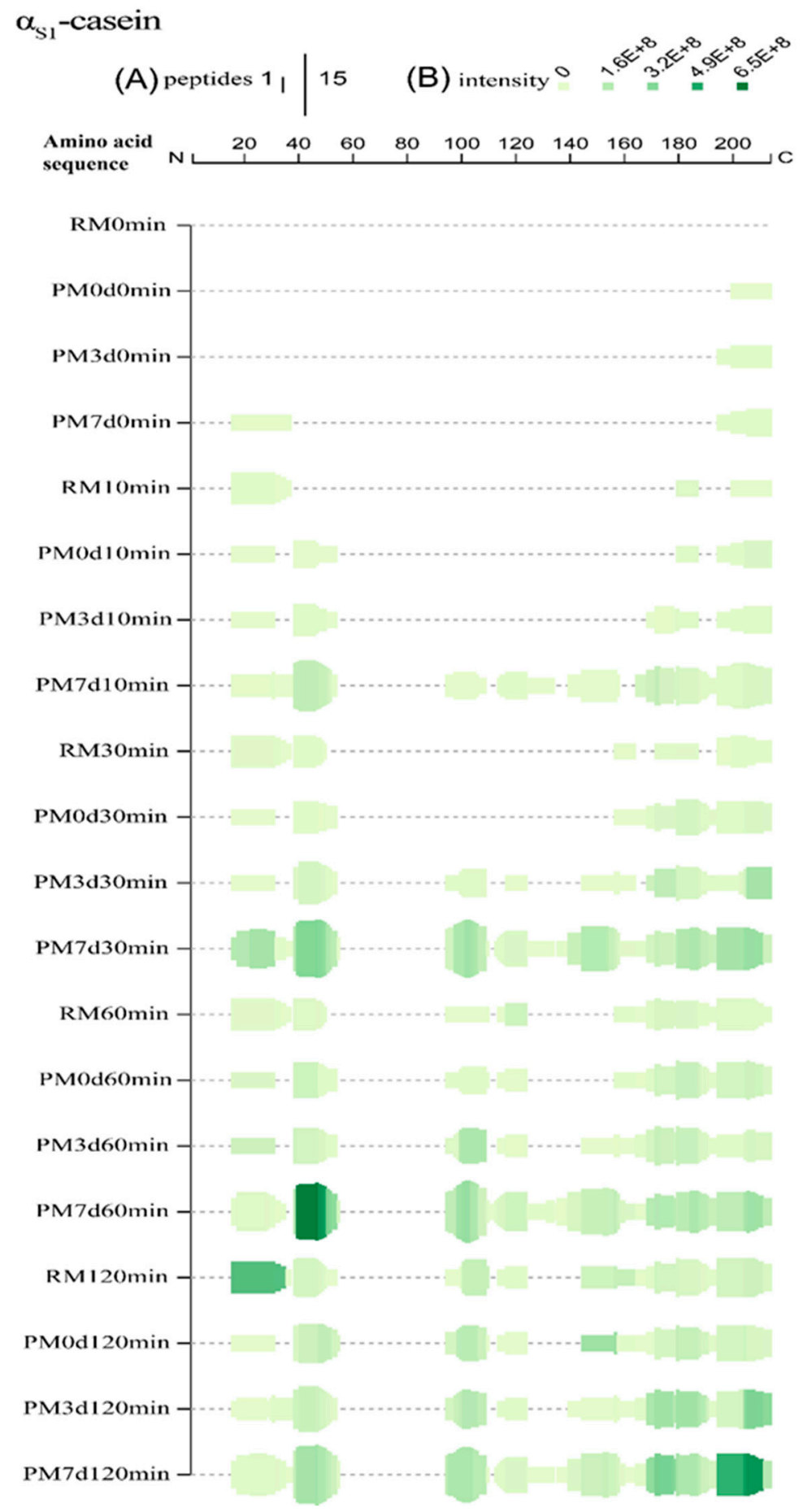

Figure 4. Peptide profiles originating from $\alpha_{\mathrm{s} 1}$-casein during the in vitro gastric digestion of raw milk (RM), pasteurized milk (PM0d), pasteurized milk upon 3 days of storage (PM3d), and pasteurized milk upon 7 days of storage (PM7d). (A) At each amino acid residue along the protein, the height of the green bars is proportional to the count of peptides overlapping this position; (B) the intensity of the color (green) is proportional to the sum of the peptide intensities overlapping this position. 

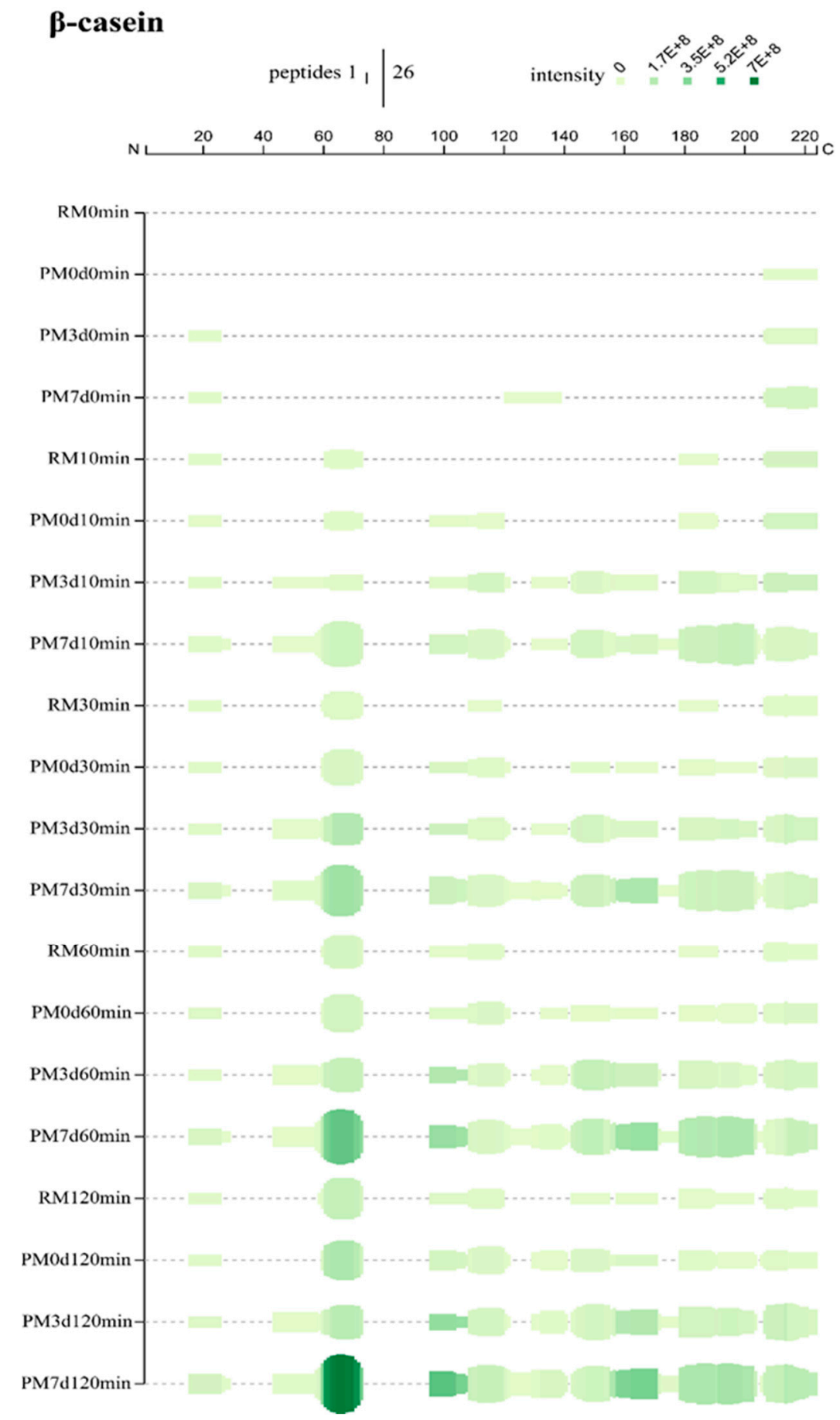

Figure 5. Peptide profiles originating from $\beta$-casein during the in vitro gastric digestion of raw milk (RM), pasteurized milk (PM0d), pasteurized milk upon 3 days of storage (PM3d), and pasteurized milk upon 7 days of storage (PM7d).

\subsection{Peptides Released during Digestion}

The peptides released during the simulated gastric digestion were further analyzed using LC-MS/MS. A Venn diagram analysis of the identified peptides from each sample is shown in Figure 6. Three hundred and forty-six peptides in all of the samples during gastric digestion (the sum of all the time points of digestion) were identified through peptide identification. More peptides were found in pasteurized milk undergoing cold storage compared with those in raw and pasteurized milk (Figure 6B). The number of specific peptides (153 peptides only found in one sample) was higher than 
the number of shared peptides (73, 41 , and 79 peptides shared by 2,3 , and 4 samples, respectively) (Figure 6C). The number of specific peptides found in the PM7d sample (145) was significantly higher than those in the RM (3), PM0d (0), and PM3d (5) sample (Figure 6A). Furthermore, a Venn diagram analysis of the peptides originating from the individual protein $\left(\alpha_{\mathrm{s} 1}-\mathrm{CN}, \alpha_{\mathrm{s} 2}-\mathrm{CN}, \beta-\mathrm{CN}, \mathrm{k}-\mathrm{CN}\right.$, and $\beta-\mathrm{Lg}$ ) in each sample under the whole process of in vitro digestion is shown in Supplementary Materials Figure S1. The visual difference performed using principal component analysis (PCA) further showed that the peptides in raw and pasteurized milk were close and revealed a significant difference between pasteurized milk during storage and raw/pasteurized milk at different digestion time points (Supplementary Materials Figure S2).

\section{(A)}

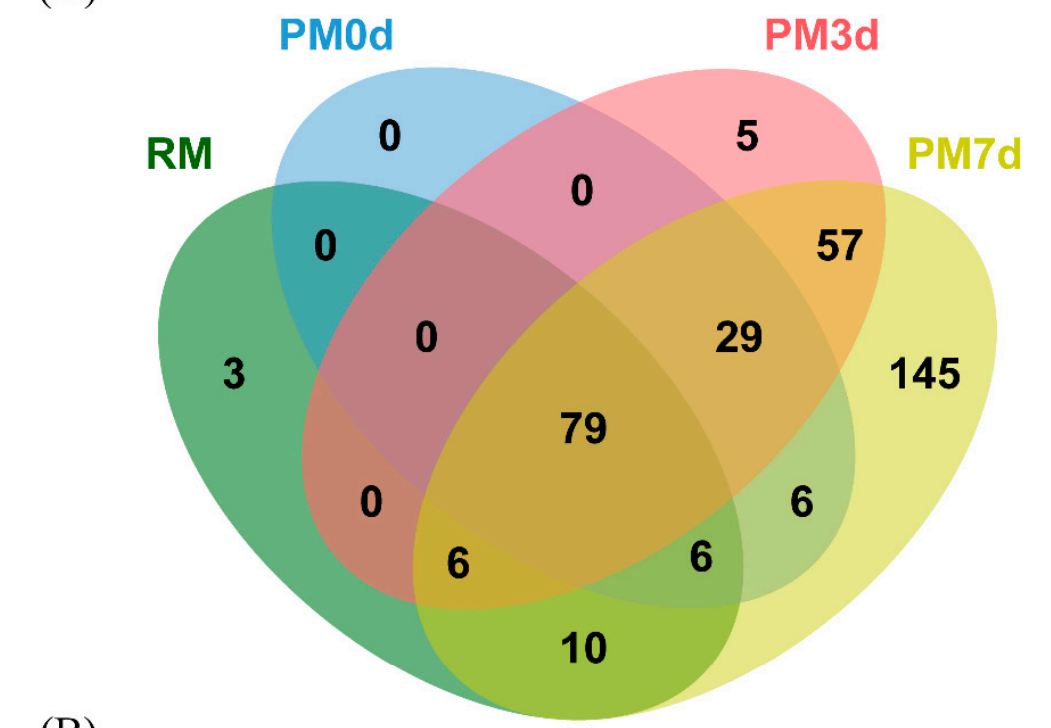

(B)

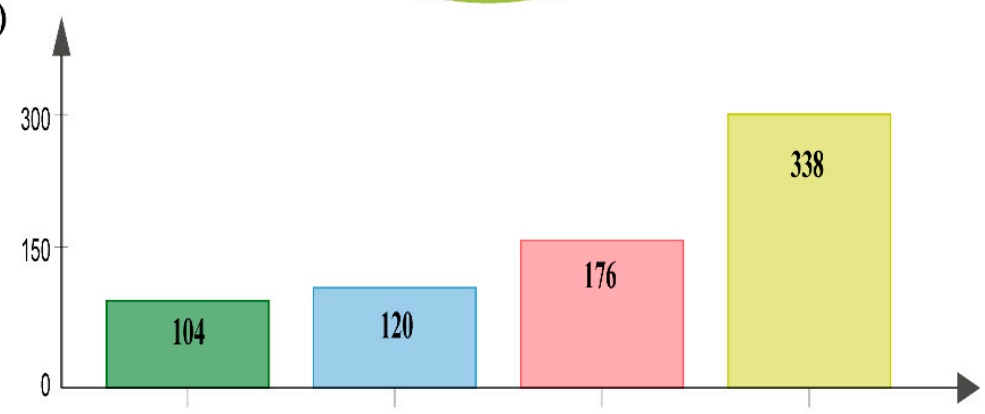

(C)

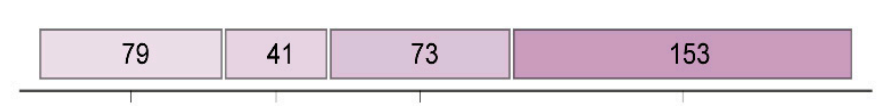

Number of peptides: specific (1) or shared by 2, 3 and 4 samples

Figure 6. Venn diagram analysis of the identified peptides (A) from raw milk (RM), pasteurized milk (PM0d), pasteurized milk upon 3 days of storage (PM3d), and pasteurized milk upon 7 days of storage (PM7d) under in vitro digestion; (B) the number of peptides identified from each sample; (C) the number of specific (1) and shared peptides by 2,3 , and 4 samples.

The peptides identified were matched with the primary structure of the major proteins $\left(\alpha_{\mathrm{s} 1}-\mathrm{CN}\right.$, $\alpha_{\mathrm{s} 2}-\mathrm{CN}, \beta-\mathrm{CN}, \mathrm{k}-\mathrm{CN}$, and $\beta-\mathrm{Lg}$ ) in milk to deduce the origins of and the differences in peptide profiles released upon pasteurization and storage at 10, 30, 60, and $120 \mathrm{~min}$ of digestion. Overall, the sequence 
coverages of the proteins upon processing and storage were increased with the time of digestion, despite a slight reduction of $\beta-\mathrm{CN}$ in PM7d at $120 \mathrm{~min}$ of digestion (Supplementary Materials Figure S3). Higher coverage rates of parent proteins in heated milk were more abundant compared to those in raw milk. A high number of peptides were found in stored milk compared to both raw and pasteurized milk at day 0 .

Peptigram, an online dynamic visualization tool, provides a summary view of the peptide profiles of samples. The height of the green bars is proportional to the count of peptides overlapping this position. The intensity of the color (green) is proportional to the sum of the peptide intensities overlapping this position. More detailed peptide alignment maps are shown in Supplementary Materials Figure S3. In general, more peptides and higher peptide intensities were identified in stored milk compared to raw and pasteurized milk at day 0 (PM7d $>$ PM3d $>$ PM0d $>$ RM) at the same digestion time point.

For $\alpha_{\mathrm{s} 1}$-casein, there was $60,57,62$, and $70 \%$ sequence coverage for raw and pasteurized milk storage at 0,3 , and $7 \mathrm{~d}$, respectively, at the end of gastric digestion (Supplementary Materials Figure S3A). At $10 \mathrm{~min}$, only three regions (f16-37, f180-187, and f200-214) were hydrolyzed in raw milk, indicating that the hydrolysis began from the N-terminal and C-terminal regions of $\alpha_{\mathrm{s} 1}-\mathrm{CN}$ (Figure 4). New regions (f39-54 and f195-200) were found in pasteurized milk. The cleavage bonds $\mathrm{Phe}_{38}-\mathrm{Phe}_{39}$ and $\mathrm{Phe}_{194}$-Ser 195 , which were buried inside the hydrophobic core [1], were not easily accessible for pepsin. Heat treatment could provide exposure of the cleavage bonds, increasing their susceptibility to hydrolysis. No significant change was observed in PM3d compared with PM0d. However, more regions (95-110, 113-134, and 140-158) were found in PM7d at 10 min of gastric digestion, indicating that hydrolysis had started from the middle regions in pasteurized milk after 7 days of cold storage. More and higher intensities of peptides were found in PM7d samples. At $30 \mathrm{~min}$, more peptides originating from new regions were identified from samples. The peptides from new regions (95-110 and 113-124) were identified in PM3d, indicating that the hydrolysis which started in the middle regions occurred in all of the pasteurized milk upon cold storage at $30 \mathrm{~min}$ of digestion. Comprehensive hydrolysis occurred in all of the samples after $120 \mathrm{~min}$ of digestion. The intensities of peptides from regions f169-179 and f195-211 in PM7d were significantly higher than those in other samples at the end of gastric digestion. In summary, more and higher intensities of peptides were identified from the regions (16-55, 95-110, and 195-210), which was consistent with previous works presenting peptidomics analyses of bovine and human milk protein-derived peptides during in vitro dynamic digestion or clinical trials [32,33]. Similar hydrolysis regions of $\alpha_{\mathrm{s} 1}-\mathrm{CN}$ were observed in all of the samples at the end of gastric digestion, although differences in peptide profiles existed in different samples during $120 \mathrm{~min}$ of digestion. More and higher intensities of peptides were found in PM7d samples compared with other samples.

$\beta$-casein, mostly present in the interior of casein micelles, is the most hydrophobic of all caseins [1]. At $10 \mathrm{~min}$, most of the peptides were from the regions between residues $\mathrm{R}_{16}-\mathrm{E}_{26}$ (N-terminal), $\mathrm{Q}_{61}-\mathrm{L}_{73}$, $\mathrm{S}_{179}-\mathrm{K}_{191}$, and $\mathrm{G}_{214}-\mathrm{V}_{224}$ (C-terminal) in raw milk, indicating that the hydrolysis started from this part of $\beta-\mathrm{CN}$ (Figure 5). Pasteurization produced new hydrolysis from the region 96-120. More hydrolysis regions were detected in pasteurized milk upon cold storage. The coverage patterns were close between PM3d and PM7d samples, while more and higher intensities of peptides were found in PM7d. Similar phenomena were also found at 30, 60, and $120 \mathrm{~min}$ of gastric digestion. At the end of digestion, there was 50, 57, 68, and 74\% sequence coverage for RM, PM0d, PM3d, and PM7d, respectively (Supplementary Materials Figure S3B). The peptides were the most numerous in PM7d compared to other samples. Moreover, the intensities of peptides in PM7d were significantly higher than the ones in other samples, especially the peptides from $\mathrm{L}_{60}-\mathrm{L}_{73}$. The peptides from the region $\mathrm{K}_{44}-\mathrm{L}_{60}$ were only identified in pasteurized milk upon storage, indicating that cold storage can make this region accessible to hydrolysis. The refrigeration of milk can induce the reversible release of $\beta-\mathrm{CN}$ from the micelle into the serum phase [5]. Our previous study showed $\sim 20 \% \beta$-CN dissociation from the casein micelles in pasteurized milk upon cooling [15]. The dissociation of $\beta-\mathrm{CN}$ would cause a 
slight loosening of the casein micelle's structure, which explained the increase in the micelle size of 14-16 nm observed after 1 day of cold storage of the pasteurized milk [15]. The loose structure of the casein micelle that formed in pasteurized milk upon cold storage could increase the availability of caseins for pepsinolysis. Moreover, $\beta-\mathrm{CN}$ in the serum may be easier to pepsin hydrolyze compared to that in the casein micelle.

Low number of peptides were identified in $\mathrm{k}-\mathrm{CN}$ compared to $\alpha_{\mathrm{s} 1}-\mathrm{CN}$ and $\beta-\mathrm{CN}$ (Supplementary Materials Figure S5A). These results were possibly due to the fact that lactosylation, glycosylation, and protein-protein interaction can increase the difficulty of $\mathrm{k}-\mathrm{CN}$ peptide sequencing [11]. Additionally, $\mathrm{k}-\mathrm{CN}$ is about three times less abundant than $\alpha_{\mathrm{s} 1}-\mathrm{CN}$ and $\beta-\mathrm{CN}$ [34]. In the initial $10 \mathrm{~min}$ of gastric digestion, most of the peptides originating from the middle regions 54-71, 88-96, and 117-126 were identified in raw milk. The number of peptides found in pasteurized milk (11 peptides) was higher than that in raw milk (7 peptides) and six peptides were common in both. Peptides from the C-terminal region 180-190 were found in PM3d and PM7d at 10 min of digestion, while in RM and PM0d, they were found at $30 \mathrm{~min}$ or more. The results indicated that cold storage could make this region easily accessible to hydrolysis. There was a minor change in peptide profiles in all of the samples at 30 and $60 \mathrm{~min}$ of digestion. The peptides from the new region 146-167 were found in all of the samples after $30 \mathrm{~min}$ of gastric digestion. The peptides from the regions $39-50$ and 127-145 were identified in all of the samples after 120 min of digestion, although these peptides were found in PM7d during the whole process of gastric digestion. Overall, $\mathrm{k}-\mathrm{CN}$ exhibited rapid hydrolysis at the initial stage of digestion and minor changes during subsequent digestion. Several regions $(22-38,98-114$, and 168-179) were found to be resistant to hydrolysis in all of the samples during digestion, suggesting that these regions were resistant to pepsin hydrolysis.

Low sequence coverage and a low number of peptides identified in $\alpha_{\mathrm{s} 2}-\mathrm{CN}$ resulted from the low content of $\alpha_{\mathrm{s} 2}-\mathrm{CN}$ in milk (Supplementary Materials Figure S5B). At the initial $10 \mathrm{~min}$ of digestion, several peptides were found in PM0d and PM3d (1 and 3 peptides in PM0d and PM3d, respectively), whereas no peptide was found in raw milk. Relatively more peptides were identified in PM7d. At $30 \mathrm{~min}$ of digestion, the peptides originating from the middle regions (96-113 and 130-138) were identified in raw milk, indicating that the hydrolysis started from these regions. More peptides were found along with the gastric digestion time. In general, the impact of heat treatment on the peptide profile of $\alpha_{\mathrm{s} 2}-\mathrm{CN}$ was limited (only one peptide ALPQYLKT was generated from PM0d at $10 \mathrm{~min}$ ). A long period of cold storage could induce the generation of more peptides. Still, many regions (such as $\mathrm{N}$-terminal, 139-161) were resistant to pepsin hydrolysis.

Low numbers of peptides from $\beta$-Lg were detected in raw milk during gastric digestion $(0,1$, 2 , and 5 peptides at 10, 30, 60, and 120 min of digestion, Supplementary Materials Figure S5C), which was consistent with native $\beta$-Lg's resistance to pepsin hydrolysis [35]. The peptides from the regions 28-44, 58-70, and 112-120 were detected in PM0d at $10 \mathrm{~min}$, indicating that pasteurization induced conformational changes in $\beta$ - Lg and thus increased the susceptibility to pepsin action [14]. No new peptides were found in PMOd at $30 \mathrm{~min}$, indicating that the hydrolysis of $\beta-\mathrm{Lg}$ in heated milk mainly occurred during the initial period of gastric digestion. Peram (7) reported that the high-molecular-weight aggregates formed by denatured $\beta$-Lg (e.g., pentamers, tetramers, and trimers) were digested rapidly, whereas native $\beta$-Lg and dimers were resistant to pepsin hydrolysis. Therefore, the hydrolysis of $\beta$-Lg in pasteurized milk during the initial period of digestion possibly resulted from the hydrolysis of high-molecular-weight aggregates. More peptides originating from new regions (i.e., 17-27, 48-58, 91-98, 99-111, and 139-165) were identified in pasteurized milk upon cold storage, especially in pasteurized milk after 7 days of storage. These results demonstrated a rapid hydrolysis of $\beta$-Lg in stored milk. Although the mechanism behind this phenomenon is not clear, it is probably due to the fact that the interaction of $\beta-\mathrm{Lg}$ and $\mathrm{k}-\mathrm{CN}$ and re-association of $\beta-\mathrm{Lg} / \mathrm{k}-\mathrm{CN}$ complexes with micelles during storage might change the structure and phase distribution of $\beta-\mathrm{Lg}$, increasing pepsin's accessibility to potential cleavage sites. 
Table 2 shows the identified bioactive peptides and their potential biological activity matched to the BIOPEP database in each sample at the end $(120 \mathrm{~min})$ of gastric digestion. Twenty-one peptides were matched to the database and the majority of these peptides had angiotensin-converting enzyme (ACE) inhibitory (52\%) and antimicrobial (29\%) functionalities; other bioactivities included immunomodulatory (19\%), DPP-IV inhibitory (14\%), and antithrombin (5\%) bioactivities. The bioactive peptides displayed different qualitative and quantitative results in each sample. For instance, the ACE-inhibitory peptide from $\alpha_{s 1}-\mathrm{CN}$ f172-179 (DAYPSGAW) was found in all of the samples. However, the content of this peptide in raw and pasteurized milk was higher than that in pasteurized milk upon storage. Therefore, processing and storage played decisive roles in bioactive peptide generation.

\subsection{Amino Acids Released during Digestion}

Understanding the pattern of amino acids during gastric digestion is an important step for better investigating milk protein metabolism, which can determine their availability and absorption in the intestinal tract. Most of the amino acids in all of the samples increased during gastric digestion (Table 3). The high level of Phe and Leu present in all of the samples at the end of digestion was due to the fact that pepsin preferentially cleaves the C-terminal end of Phe and Leu [36]. The levels of the majority of free amino acids in stored pasteurized milk were higher than pasteurized milk and those in pasteurized milk were higher than raw milk at $120 \mathrm{~min}$, except for Lys. This might be due to the fact that glycation and lactosylation modify the side chains of proteins, inducing the blocking of Lys residues to hydrolysis [37]. In general, the higher levels of amino acids found in PM7d indicated that rapid hydrolysis occurred in pasteurized milk upon cold storage, which was consistent with the results of LC-MSMS. 
Table 2. Bioactive peptides identified after the gastric digestion of raw milk (RM), pasteurized milk (PM0d), and pasteurized milk during storage (PM3d and PM7d) with the BIOPEP database, and the digestive time $(\mathrm{min})$ at which they were identified in each sample.

\begin{tabular}{|c|c|c|c|c|c|c|c|c|}
\hline \multirow{2}{*}{ Protein } & \multirow{2}{*}{ Sequence } & \multirow{2}{*}{ Residues } & \multirow{2}{*}{ Bioactivity } & \multirow{2}{*}{ References ${ }^{1}$} & \multicolumn{4}{|c|}{ Samples $^{2}$} \\
\hline & & & & & $\mathbf{R M}$ & PM0d & PM3d & PM7d \\
\hline \multirow[t]{5}{*}{$\alpha_{s 1}-C N$} & FVAPFPEVFG & $39-48$ & ACE-inhibitory & [1] & 1.82 & 0.00 & 1.69 & 1.00 \\
\hline & LRLKKYKVPQL & $114-124$ & Antimicrobial & {$[2,3]$} & 3.19 & 1.00 & 3.67 & 3.12 \\
\hline & LAYFYPEL & $157-164$ & Immunomodulatory & [4] & 77.44 & 5.32 & 2.10 & 1.00 \\
\hline & DAYPSGAW & $172-179$ & ACE-inhibitory & [5] & 12.64 & 11.76 & 8.48 & 1.00 \\
\hline & SDIPNPIGSENSEK & $195-208$ & Antimicrobial & [6] & 1.00 & 2.69 & 1.47 & 1.95 \\
\hline \multirow[t]{10}{*}{$\beta-C N$} & VENLHLPLPLL & $145-155$ & ACE-inhibitory & [1] & 0.00 & 0.00 & 10.86 & 1.00 \\
\hline & NLHLPLPLL & 147-155 & ACE-inhibitory & [1] & 0.00 & 0.00 & 1.53 & 1.00 \\
\hline & LYQEPVLGPVRGPFPIIV & $207-224$ & Immunomodulatory & [7] & 0.00 & 0.00 & 1.00 & 0.00 \\
\hline & YQEPVLGPVR & $208-217$ & ACE-inhibitory & [8] & 0.00 & 0.00 & 2.97 & 1.00 \\
\hline & & & Immunomodulatory & [9] & & & & \\
\hline & YQEPVLGPVRG & $208-218$ & ACE-inhibitory & [10] & 0.00 & 0.00 & 4.36 & 1.00 \\
\hline & YQEPVLGPVRGPFPIIV & $208-224$ & Immunomodulatory & [11] & 3.52 & 5.75 & 2.78 & 1.00 \\
\hline & & & antithrombin & [12] & & & & \\
\hline & & & Antimicrobial & [13] & & & & \\
\hline & & & ACE-inhibitory & [14] & & & & \\
\hline \multirow[t]{4}{*}{$\kappa-C N$} & YYQQKPVA & $63-70$ & Antimicrobial & [15] & 1.00 & 1.05 & 1.66 & 2.33 \\
\hline & HPHPHLSF & $119-126$ & ACE-inhibitory & {$[16]$} & 0.00 & 0.00 & 2.06 & 1.00 \\
\hline & MAIPPKKNQDKTEIPTINT & $127-145$ & Antimicrobial & [17] & 1.00 & 0.00 & 0.00 & 0.00 \\
\hline & VESTVATL & $160-167$ & Antimicrobial & [15] & 1.01 & 1.00 & 1.36 & 4.27 \\
\hline \multirow[t]{7}{*}{$\beta-L g$} & LIVTQTMK & $17-24$ & Cytotoxic & [18] & 0.00 & 0.00 & 0.00 & 1.00 \\
\hline & LDIQKVAGTW & $26-35$ & ACE-inhibitory & [19] & 0.00 & 1.00 & 0.00 & 27.83 \\
\hline & IQKVAGTW & $28-35$ & DPP-IV Inhibitory & [19] & 0.00 & 1.21 & 2.56 & 6.49 \\
\hline & & & ACE-inhibitory & [19] & & & & \\
\hline & DAQSAPLRVY & $49-58$ & ACE-inhibitory & {$[20,21]$} & 0.00 & 0.00 & 0.00 & 1.00 \\
\hline & LKPTPEGDL & $62-70$ & DPP-IV Inhibitory & [22] & 0.00 & 0.00 & 0.00 & 1.00 \\
\hline & LKPTPEGDLE & $42-71$ & DPP-IV Inhibitory & [22] & 0.00 & 0.00 & 0.00 & 1.00 \\
\hline
\end{tabular}

${ }^{1}$ References are listed in Supplementary Materials Table S1. ${ }^{2}$ The intensities of the specific bioactive peptide in different samples are normalized to the sample which has the lowest intensity of the peptide. 0.00 means not detected. 
Table 3. Composition and content (mg/100 g) of free amino acids released from raw milk (RM), pasteurized milk (PM0d), pasteurized milk upon 3 days of storage (PM3d), and pasteurized milk upon 7 days of storage (PM7d) at 30, 60, and 120 min of gastric in vitro digestion.

\begin{tabular}{|c|c|c|c|c|c|c|c|c|c|c|c|c|}
\hline \multirow{3}{*}{ Amino Acid } & \multicolumn{12}{|c|}{ Amino Acid Released during Digestion } \\
\hline & \multicolumn{4}{|c|}{$30 \mathrm{~min}$} & \multicolumn{4}{|c|}{$60 \mathrm{~min}$} & \multicolumn{4}{|c|}{$120 \mathrm{~min}$} \\
\hline & RM & PM0d & PM3d & PM7d & $\mathbf{R M}$ & PM0d & PM3d & PM7d & RM & PMOd & PM3d & PM7d \\
\hline \multicolumn{13}{|c|}{ Essential amino acid } \\
\hline Thr & $0.1 \pm 0^{\mathrm{aA}}$ & $0.1 \pm 0.1^{\mathrm{aA}}$ & $0.3 \pm 0.1 \mathrm{aA}$ & $0.8 \pm 0.1^{\mathrm{bA}}$ & $0.2 \pm 0.1^{\mathrm{aA}}$ & $0.2 \pm 0.1 \mathrm{aA}$ & $0.3 \pm 0.1^{\mathrm{aA}}$ & $2.6 \pm 0.2^{\mathrm{bB}}$ & $0.6 \pm 0.1 \mathrm{aB}$ & $1.2 \pm 0.2^{\mathrm{bB}}$ & $2.7 \pm 0.3^{\mathrm{cB}}$ & $4.6 \pm 0.1 \mathrm{dC}$ \\
\hline Cys & $0.2 \pm 0.1^{\mathrm{aA}}$ & $0.4 \pm 0.2^{\mathrm{aA}}$ & $0.6 \pm 0.1^{\mathrm{aA}}$ & $1.4 \pm 0.2^{\mathrm{bA}}$ & $0.3 \pm 0.1^{\mathrm{aA}}$ & $0.3 \pm 0.2^{\mathrm{aA}}$ & $0.4 \pm 0.2^{\mathrm{aA}}$ & $1.9 \pm 0.2^{b B}$ & $0.6 \pm 0.2^{\mathrm{aB}}$ & $0.8 \pm 0.3^{\mathrm{bB}}$ & $1.5 \pm 0.1^{\mathrm{cB}}$ & $2.8 \pm 0.3 \mathrm{dC}$ \\
\hline Lys & $0.4 \pm 0.3^{\mathrm{aA}}$ & $0.4 \pm 0.1^{\mathrm{aA}}$ & $0.6 \pm 0.2^{\mathrm{aA}}$ & $1.6 \pm 0.2^{\mathrm{bA}}$ & $2.7 \pm 0.1 \mathrm{aB}$ & $1.4 \pm 0.1 \mathrm{bB}$ & $1.3 \pm 0.1 \mathrm{bB}$ & $3.6 \pm 0.2^{\mathrm{cB}}$ & $5.9 \pm 0.3^{\mathrm{aC}}$ & $2.6 \pm 0.2^{b C}$ & $3.6 \pm 0.2^{\mathrm{aC}}$ & $3.5 \pm 0.3^{\mathrm{cB}}$ \\
\hline Met & $0.5 \pm 0.3^{\mathrm{aA}}$ & $0.5 \pm 0.2^{\mathrm{aA}}$ & $0.7 \pm 0.2^{\mathrm{aA}}$ & $0.8 \pm 0.1^{\mathrm{aA}}$ & $0.6 \pm 0.1^{\mathrm{aA}}$ & $0.6 \pm 0.2^{\mathrm{aA}}$ & $0.7 \pm 0.2^{\mathrm{aA}}$ & $1.3 \pm 0.1^{\mathrm{bB}}$ & $0.8 \pm 0.1^{\mathrm{aA}}$ & $1.1 \pm 0.2^{\mathrm{bB}}$ & $2.6 \pm 0.1 \mathrm{bC}$ & $5.7 \pm 0.2^{\mathrm{cC}}$ \\
\hline Phe & $1.9 \pm 0.2^{\mathrm{aA}}$ & $2.1 \pm 0 \mathrm{abA}$ & $2.3 \pm 0.1 \mathrm{bA}$ & $2.7 \pm 0.3^{\mathrm{cA}}$ & $3.5 \pm 0.2^{\mathrm{aB}}$ & $4.4 \pm 0.2^{\mathrm{bB}}$ & $5.1 \pm 0.1 \mathrm{cB}$ & $8.2 \pm 0.2 \mathrm{~dB}$ & $9.6 \pm 0.2 \mathrm{aC}$ & $11.1 \pm 0.2 \mathrm{bC}$ & $11.5 \pm 0.3 \mathrm{bC}$ & $11.5 \pm 0.4 \mathrm{bC}$ \\
\hline Ile & $0.1 \pm 0.1^{\mathrm{aA}}$ & $0.1 \pm 0^{\mathrm{aA}}$ & $0.3 \pm 0.1 \mathrm{bA}$ & $0.4 \pm 0.1 \mathrm{bA}$ & $0.2 \pm 0.1^{\mathrm{aA}}$ & $0.4 \pm 0.1^{\mathrm{bB}}$ & $0.4 \pm 0^{\mathrm{bA}}$ & $0.9 \pm 0.1^{\mathrm{cB}}$ & $0.3 \pm 0.1^{\mathrm{aA}}$ & $0.9 \pm 0.1^{b C}$ & $2.2 \pm 0.2^{\mathrm{cB}}$ & $3.3 \pm 0.2 \mathrm{dC}$ \\
\hline Leu & $0.8 \pm 0.1^{\mathrm{aA}}$ & $1.1 \pm 0.2 \mathrm{abA}$ & $1.3 \pm 0.1^{\mathrm{bA}}$ & $1.8 \pm 0.2^{\mathrm{aA}}$ & $2.0 \pm 0.2^{\mathrm{aB}}$ & $2.4 \pm 0.2^{\mathrm{aB}}$ & $3.0 \pm 0.1^{\mathrm{cB}}$ & $5.1 \pm 0.2 \mathrm{~dB}$ & $6.6 \pm 0.2 \mathrm{aC}$ & $7.4 \pm 0.3^{\mathrm{bB}}$ & $8.1 \pm 0.2^{\mathrm{cB}}$ & $8.7 \pm 0.3 \mathrm{dC}$ \\
\hline His & $0.1 \pm 0 \mathrm{aA}$ & $0.1 \pm 0^{\mathrm{aA}}$ & $0.1 \pm 0^{\mathrm{aA}}$ & $0.1 \pm 0^{\mathrm{aA}}$ & $0.2 \pm 0.2 \mathrm{aA}$ & $0.1 \pm 0^{\mathrm{aA}}$ & $0.3 \pm 0.2 \mathrm{aA}$ & $0.6 \pm 0.1 \mathrm{bB}$ & $0.4 \pm 0.1 \mathrm{aB}$ & $2.3 \pm 0.2^{\mathrm{aB}}$ & $2.9 \pm 0.1^{\mathrm{cB}}$ & $4.1 \pm 0.2 \mathrm{dC}$ \\
\hline Tyr & $0.6 \pm 0.1^{\mathrm{aA}}$ & $0.6 \pm 0.1^{\mathrm{aA}}$ & $0.7 \pm 0.1 \mathrm{aA}$ & $3.2 \pm 0.1 \mathrm{bA}$ & $0.6 \pm 0.1 \mathrm{aA}$ & $0.6 \pm 0.1 \mathrm{aA}$ & $0.9 \pm 0^{\mathrm{bA}}$ & $2.6 \pm 0.1^{\mathrm{cB}}$ & $0.8 \pm 0.1 \mathrm{aA}$ & $1.4 \pm 0.2^{\mathrm{bB}}$ & $3.2 \pm 0.3^{\mathrm{cB}}$ & $5.1 \pm 0.5 \mathrm{dC}$ \\
\hline Val & $0.9 \pm 0.1 \mathrm{aA}$ & $1.1 \pm 0.1 \mathrm{aA}$ & $1.0 \pm 0.1^{\mathrm{aA}}$ & $1.7 \pm 0.2^{\mathrm{bA}}$ & $0.9 \pm 0.1 \mathrm{aA}$ & $0.9 \pm 0.1^{\mathrm{aA}}$ & $1.1 \pm 0.2 \mathrm{aA}$ & $2.7 \pm 0.2^{\mathrm{bB}}$ & $1.1 \pm 0.2^{\mathrm{aA}}$ & $1.9 \pm 0.1^{\mathrm{bB}}$ & $2.7 \pm 0.2^{\mathrm{cB}}$ & $4.4 \pm 0.5 \mathrm{dC}$ \\
\hline \multicolumn{13}{|c|}{ Non-essential amino acid } \\
\hline Ser & $0.1 \pm 0^{\mathrm{aA}}$ & $0.1 \pm 0^{\mathrm{aA}}$ & $0.2 \pm 0 \mathrm{aA}$ & $0.4 \pm 0.1 \mathrm{bA}$ & $0.4 \pm 0.1 \mathrm{aB}$ & $0.4 \pm 0.1 \mathrm{aA}$ & $0.4 \pm 0.1 \mathrm{aA}$ & $0.9 \pm 0.1 \mathrm{bB}$ & $0.7 \pm 0.2 \mathrm{aC}$ & $1.4 \pm 0.2^{\mathrm{bB}}$ & $1.7 \pm 0.3 \mathrm{bB}$ & $3.2 \pm 0.2^{\mathrm{cC}}$ \\
\hline Arg & $0.5 \pm 0.1^{\mathrm{aA}}$ & $0.6 \pm 0.1 \mathrm{aA}$ & $0.9 \pm 0.2^{\mathrm{aB}}$ & $1.2 \pm 0.2^{\mathrm{cA}}$ & $0.8 \pm 0.1^{\mathrm{aA}}$ & $1.1 \pm 0.2^{\mathrm{bA}}$ & $1.1 \pm 0.2^{\mathrm{aA}}$ & $3.6 \pm 0.2^{b B}$ & $1.6 \pm 0.1^{\mathrm{aA}}$ & $2.2 \pm 0.1^{b B}$ & $2.4 \pm 0.2^{\mathrm{bB}}$ & $6.0 \pm 0.4^{\mathrm{cC}}$ \\
\hline Asp & $0.2 \pm 0.1^{\mathrm{aA}}$ & $0.2 \pm 0.1^{\mathrm{aA}}$ & $0.3 \pm 0.2 \mathrm{aA}$ & $0.5 \pm 0.1 \mathrm{bA}$ & $0.3 \pm 0.3^{\mathrm{aA}}$ & $0.5 \pm 0.2^{\mathrm{aA}}$ & $0.6 \pm 0.3 \mathrm{aB}$ & $0.8 \pm 0.2^{\mathrm{aB}}$ & $0.4 \pm 0.2^{\mathrm{aA}}$ & $0.8 \pm 0.2^{\mathrm{bA}}$ & $0.8 \pm 0.2^{b B}$ & $1.4 \pm 0.00^{\mathrm{cC}}$ \\
\hline Gly & $0.6 \pm 0.1 \mathrm{aA}$ & $0.6 \pm 0.2^{\mathrm{aA}}$ & $0.8 \pm 0.2 \mathrm{aA}$ & $0.9 \pm 0.2 \mathrm{aA}$ & $0.7 \pm 0.2 \mathrm{aA}$ & $0.9 \pm 0.2 \mathrm{aA}$ & $0.9 \pm 0.2 \mathrm{aA}$ & $1.2 \pm 0.1 \mathrm{aB}$ & $0.9 \pm 0.2 \mathrm{aA}$ & $1.4 \pm 0.2 \mathrm{bC}$ & $1.6 \pm 0.1 \mathrm{bB}$ & $2.4 \pm 0.2^{\mathrm{cC}}$ \\
\hline Glu & $5.4 \pm 0.1 \mathrm{aA}$ & $5.4 \pm 0.1^{\mathrm{aA}}$ & $5.7 \pm 0.2^{\mathrm{aA}}$ & $6.8 \pm 0.2^{\mathrm{bA}}$ & $5.5 \pm 0.2 \mathrm{aA}$ & $5.7 \pm 0.2^{\mathrm{aA}}$ & $6.0 \pm 0.2 \mathrm{aA}$ & $7.8 \pm 0.2^{\mathrm{bB}}$ & $6.4 \pm 0.2^{\mathrm{aB}}$ & $8.0 \pm 0.2^{\mathrm{bB}}$ & $8.5 \pm 0.1^{\mathrm{cB}}$ & $9.2 \pm 0.1 \mathrm{dC}$ \\
\hline Ala & $0.4 \pm 0.1 \mathrm{aA}$ & $0.4 \pm 0.1 \mathrm{aA}$ & $0.5 \pm 0.2^{\mathrm{aA}}$ & $0.7 \pm 0.1 \mathrm{aA}$ & $0.5 \pm 0.1 \mathrm{aA}$ & $0.5 \pm 0.1^{\mathrm{aA}}$ & $0.6 \pm 0.2 \mathrm{aA}$ & $1.7 \pm 0.2^{\mathrm{bB}}$ & $0.7 \pm 0.2^{\mathrm{aA}}$ & $1.5 \pm 0.2^{\mathrm{bB}}$ & $3.5 \pm 0.2^{\mathrm{cB}}$ & $4.5 \pm 0.2 \mathrm{dC}$ \\
\hline Pro & $0.5 \pm 0.1^{\mathrm{aA}}$ & $0.5 \pm 0.1^{\mathrm{aA}}$ & $0.6 \pm 0.2^{\mathrm{aA}}$ & $0.9 \pm 0.2^{\mathrm{bA}}$ & $0.7 \pm 0.2^{\mathrm{aA}}$ & $0.7 \pm 0.2^{\mathrm{aA}}$ & $0.7 \pm 0.1 \mathrm{aA}$ & $1.1 \pm 0.1^{\mathrm{bA}}$ & $1.1 \pm 0.1^{\mathrm{aA}}$ & $1.8 \pm 0.1^{\mathrm{bB}}$ & $2.3 \pm 0.2^{\mathrm{cB}}$ & $2.6 \pm 0.2 \mathrm{~dB}$ \\
\hline Total & $13.4^{\mathrm{aA}}$ & $14.1^{\mathrm{aA}}$ & $17.1^{\mathrm{bA}}$ & $25.7^{\mathrm{cA}}$ & $22.4^{\mathrm{aB}}$ & $21.8^{\mathrm{aB}}$ & $23.2^{\mathrm{aB}}$ & $47.4^{\mathrm{bB}}$ & $38.5^{\mathrm{aC}}$ & $47.8^{\mathrm{bC}}$ & $62.4^{\mathrm{cC}}$ & $86.2 \mathrm{dC}$ \\
\hline
\end{tabular}

Data shown (mean + standard deviation) are the mean values of three independent samples and each was measured in triplicate. Values in a row with different lowercase superscripts (a-c)

F differ significantly $(p<0.05)$ in different samples at the same digestion time. Values in a row with different uppercase superscripts $(\mathrm{A}-\mathrm{C})$ differ significantly $(p<0.05)$ in each sample at different digestion times. 


\section{Conclusions}

The coagulation behavior of milk and protein digestibility were investigated in pasteurized milk upon storage under dynamic in vitro gastric digestion. A high level of hydration in curds formed in pasteurized milk upon 7-day cold storage compared to raw and pasteurized milk indicated that pepsin could easily enter the interior of curds, increasing the digestion rate. The results obtained from OPA, SDS-PAGE, LC-MSMS, and amino acid analysis further revealed that rapid hydrolysis of milk proteins occurred in pasteurized milk upon cold storage. Higher intensities of peptides were found in pasteurized milk upon subsequent storage. The peptide patterns in different samples at different digestion times were different, which indicated that the protein digestibility was altered upon pasteurization and cold storage. Moreover, heat treatment and storage played decisive roles in bioactive peptide generation. This study can provide insights into and directions for the storage of pasteurized milk for further clinical studies to assess whether the release of bioactive peptides at specific time points during digestion could yield a modified physiological response, thereby resulting in desired health outcomes. Further research is needed to determine site-specific protein modifications during storage and their relationship to in vitro and in vivo protein digestibility.

Supplementary Materials: The following are available online at http://www.mdpi.com/2304-8158/9/8/998/s1. Table S1: List of references for the bioactive peptides in Table 1; Figure S1: Venn diagram analysis of the identified peptides from $\alpha_{\mathrm{s} 1}$-casein (A), $\alpha_{\mathrm{s} 2}$-casein (B), $\beta$-casein (C), $\mathrm{k}$-casein (D), and $\beta$-Lg (E) in raw milk (RM), pasteurized milk (PM0d), pasteurized milk upon 3 days of storage (PM3d), and pasteurized milk upon 7 days of storage (PM7d) during the whole in vitro digestion process; Figure S2. PCA score plots of the identified peptides from raw milk (RM), pasteurized milk (PM0d), pasteurized milk upon 3 days of storage (PM3d), and pasteurized milk upon 7 days of storage (PM7d) at 10, 30, 60, and $120 \mathrm{~min}$ of in vitro gastric digestion; Figure S3: Peptide coverages of parent protein sequences (A: $\alpha_{\mathrm{S} 1}$-casein, B: $\beta$-casein, C: $\kappa$-casein, $\mathrm{D}: \alpha_{\mathrm{S} 2}$-casein, and E: $\beta$-lactoglobulin) from raw milk (RM), pasteurized milk (PM0d), pasteurized milk upon 3 days of storage (PM3d), and pasteurized milk upon 7 days of storage (PM7d) at 10, 30, 60, and 120 min of digestion; Figure S4: Peptide alignment maps originating from $\alpha_{\mathrm{s} 1}$-casein, $\alpha_{\mathrm{s} 2}$-casein, $\beta$-casein, $\mathrm{k}$-casein, and $\beta$-lactoglobulin $(\beta-\mathrm{lg})$ during the in vitro gastric digestion of raw milk (RM), pasteurized milk (PM0d), pasteurized milk upon 3 days of storage (PM3d), and pasteurized

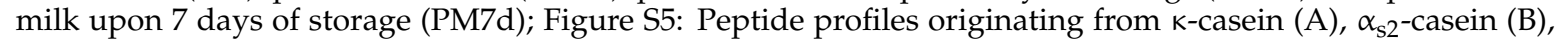
and $\beta$-lactoglobulin $(\beta-\mathrm{lg}, \mathrm{C})$ during the in vitro gastric digestion of raw milk (RM), pasteurized milk (PM0d), pasteurized milk upon 3 days of storage (PM3d), and pasteurized milk upon 7 days of storage (PM7d).

Author Contributions: Conceptualization, X.L. and Y.M.; methodology, X.L. and Y.M.; software, X.L. and Y.G; validation, X.L., Y.G. and S.H.; formal analysis, X.L. and O.E.D.; resources, Y.M.; data curation, X.L.; writing-original draft preparation, X.L., Q.L. and H.L.; writing-review and editing, X.L., Q.L. and H.L.; visualization, X.L. and S.H.; supervision, Y.M.; project administration, Y.M.; funding acquisition, Y.M. All authors have read and agreed to the published version of the manuscript.

Funding: This work was funded by the SICHUAN SCIENCE AND TECHNOLOGY PLAN PROGRAM (No. 2019YFN0119).

Conflicts of Interest: The authors declare no conflict of interest.

\section{References}

1. Rinaldi, L.; Gauthier, S.F.; Britten, M.; Turgeon, S.L. In vitro gastrointestinal digestion of liquid and semi-liquid dairy matrixes. Lwt-Food Sci. Technol. 2014, 57, 99-105. [CrossRef]

2. Sánchez-Rivera, L.; Martínez-Maqueda, D.; Cruz-Huerta, E.; Miralles, B.; Recio, I. Peptidomics for discovery, bioavailability and monitoring of dairy bioactive peptides. Food Res. Int. 2014, 63, 170-181.

3. Dalgleish, D.G.; Corredig, M. The structure of the casein micelle of milk and its changes during processing. Annu. Rev. Food Sci. Technol. 2012, 3, 449-467. [CrossRef] [PubMed]

4. Jean, K.; Renan, M.; Famelart, M.H.; Guyomarc'h, F. Structure and surface properties of the serum heat-induced protein aggregates isolated from heated skim milk. Int. Dairy J. 2006, 16, 303-315. [CrossRef]

5. Anema, S.G.; Lowe, E.K.; Lee, S.K.; Klostermeyer, H. Effect of the pH of skim milk at heating on milk concentrate viscosity. Int. Dairy J. 2014, 39, 336-343. [CrossRef]

6. Sava, N.; Van der Plancken, I.; Claeys, W.; Hendrickx, M. The kinetics of heat-induced structural changes of beta-lactoglobulin. J. Dairy Sci. 2005, 88, 1646-1653. [CrossRef]

7. Anema, S.G.; Lowe, E.K.; Li, Y. Effect of $\mathrm{pH}$ on the viscosity of heated reconstituted skim milk. Int. Dairy J. 2004, 14, 541-548. [CrossRef] 
8. Peram, M.R.; Loveday, S.M.; Ye, A.; Singh, H. In vitro gastric digestion of heat-induced aggregates of beta-lactoglobulin. J. Dairy Sci. 2013, 96, 63-74. [CrossRef]

9. Ye, A.; Cui, J.; Dalgleish, D.; Singh, H. Formation of a structured clot during the gastric digestion of milk: Impact on the rate of protein hydrolysis. Food Hydrocoll. 2016, 52, 478-486. [CrossRef]

10. Dupont, D.; Mandalari, G.; Molle, D.; Jardin, J.; Rolet-Repecaud, O.; Duboz, G.; Leonil, J.; Mills, C.E.; Mackie, A.R. Food processing increases casein resistance to simulated infant digestion. Mol. Nutr. Food Res. 2010, 54, 1677-1689. [CrossRef]

11. Sánchez-Rivera, L.; Ménard, O.; Recio, I.; Dupont, D. Peptide mapping during dynamic gastric digestion of heated and unheated skimmed milk powder. Food Res. Int. 2015, 77, 132-139. [CrossRef]

12. Dupont, D.; Mandalari, G.; Molle, D.; Jardin, J.; Leonil, J.; Faulks, R.M.; Wickham, M.S.; Mills, E.N.; Mackie, A.R. Comparative resistance of food proteins to adult and infant in vitro digestion models. Mol. Nutr. Food Res. 2010, 54, 767-780. [CrossRef] [PubMed]

13. Ravanis, S.; Lewis, M.J. Observations on the effect of raw milk quality on the keeping quality of pasteurized milk. Lett. Appl. Microbiol. 1995, 20, 164-167. [CrossRef] [PubMed]

14. Liu, H.; Grosvenor, A.J.; Li, X.; Wang, X.L.; Ma, Y.; Clerens, S.; Dyer, J.M.; Day, L. Changes in milk protein interactions and associated molecular modification resulting from thermal treatments and storage. J. Food Sci. 2019, 84, 1737-1745. [CrossRef] [PubMed]

15. Li, X.; Li, L.; Ma, Y.; Wang, R.; Gu, Y.; Day, L. Changes in protein interactions in pasteurized milk during cold storage. Food Biosci. 2020, 34, 100530. [CrossRef]

16. Kong, F.; Singh, R.P. A human gastric simulator (HGS) to study food digestion in human stomach. J. Food Sci. 2010, 75, 627-635. [CrossRef]

17. Minekus, M.; Alminger, M.; Alvito, P.; Ballance, S.; Bohn, T.; Bourlieu, C.; Carrière, F.; Boutrou, R.; Corredig, M.; Dupont, D. A standardised static in vitro digestion method suitable for food-an international consensus. Food Funct. 2014, 5, 1113-1124. [CrossRef]

18. Chen, J.; Gaikwad, V.; Holmes, M.; Murray, B.; Povey, M.; Wang, Y.; Zhang, Y. Development of a simple model device for in vitro gastric digestion investigation. Food Funct. 2011, 2, 174-182. [CrossRef]

19. Schulze, K. Imaging and modelling of digestion in the stomach and the duodenum. Neurogastroenterol. Motil. 2006, 18, 172-183. [CrossRef]

20. Ye, A.; Cui, J.; Dalgleish, D.; Singh, H. The formation and breakdown of structured clots from whole milk during gastric digestion. Food Funct. 2016, 7, 4259-4266. [CrossRef]

21. He, S.; Gu, C.; Wang, D.; Xu, W.; Wang, R.; Ma, Y. The stability and in vitro digestion of curcumin emulsions containing konjac glucomannan. Lwt Food Sci. Technol. 2020, 117. [CrossRef]

22. Nehir, E.S.; Karakaya, S.; Simsek, S.; Dupont, D.; Menfaatli, E.; Eker, A.T. In vitro digestibility of goat milk and kefir with a new standardised static digestion method (infogest cost action) and bioactivities of the resultant peptides. Food Funct. 2015, 6, 2322-2330. [CrossRef] [PubMed]

23. Ji, X.; Li, X.; Ma, Y.; Li, D. Differences in proteomic profiles of milk fat globule membrane in yak and cow milk. Food Chem. 2017, 221, 1822. [CrossRef] [PubMed]

24. Manguy, J.; Jehl, P.; Dillon, E.T.; Davey, N.E.; Shields, D.C.; Holton, T.A. Peptigram: A web-based application for peptidomics data visualization. J. Proteome Res. 2017, 16, 712-719. [CrossRef]

25. Lorieau, L.; Halabi, A.; Ligneul, A.; Hazart, E.; Dupont, D.; Floury, J. Impact of the dairy product structure and protein nature on the proteolysis and amino acid bioaccessiblity during in vitro digestion. Food Hydrocoll. 2018, 82, 399-411. [CrossRef]

26. Tam, J.J.; Whitaker, J.R. Rates and extents of hydrolysis of several caseins by pepsin, rennin, endothia parasitica protease and mucor pusillus protease. J. Dairy Sci. 1972, 55, 1523-1531. [CrossRef]

27. Miranda, G.; Pelissier, J.P. Kinetic studies of in vivo digestion of bovine unheated skim-milk proteins in the rat stomach. J. Dairy Res. 1983, 50, 27-36. [CrossRef]

28. And, N.K.; Kinekawa, Y.I. Digestibility of bovine milk whey protein and $\beta$-lactoglobulin in vitro and in vivo. J. Agric. Food Chem. 1998, 46, 4917-4923.

29. Reddy, I.M.; Kella, N.K.D.; Kinsella, J.E. Structural and conformational basis of the resistance of Beta-lactoglobulin to peptic and chymotryptic digestion. J. Agric. Food Chem. 1988, 36, 737-741. [CrossRef]

30. Post, A.E.; Arnold, B.; Weiss, J.; Hinrichs, J. Effect of temperature and pH on the solubility of caseins: Environmental influences on the dissociation of alpha(s)- and beta-casein. J. Dairy Sci. 2012, 95, 1603-1616. [CrossRef] 
31. Ismail, B.; Nielsen, S.S. Invited review: Plasmin protease in milk: Current knowledge and relevance to dairy industry. J. Dairy Sci. 2010, 93, 4999-5009. [CrossRef] [PubMed]

32. Beverly, R.L.; Underwood, M.A.; Dallas, D.C. Peptidomics Analysis of Milk Protein-Derived Peptides Released over Time in the Preterm Infant Stomach. J. Proteome Res. 2019, 18, 912-922. [CrossRef] [PubMed]

33. Deglaire, A.; Oliveira, S.; Jardin, J.; Briard-Bion, V.; Kroell, F.; Emily, M.; Menard, O.; Bourlieu, C.; Dupont, D. Impact of human milk pasteurization on the kinetics of peptide release during in vitro dynamic digestion at the preterm newborn stage. Food Chem. 2019, 281, 294-303. [CrossRef] [PubMed]

34. Dupont, D.; Boutrou, R.; Menard, O.; Jardin, J.; Tanguy, G.; Schuck, P.; Haab, B.B.; Leonil, J. Heat treatment of milk during powder manufacture increases casein resistance to simulated infant digestion. Food Digestion. 2010, 1, 28-39. [CrossRef]

35. Guo, M.R.; Fox, P.F.; Flynn, A.; Kindstedt, P.S. Susceptibility of beta-lactoglobulin and sodium caseinate to proteolysis by pepsin and trypsin. J. Dairy Sci. 1995, 78, 2336. [CrossRef]

36. Ao, J.; Li, B. Stability and antioxidative activities of casein peptide fractions during simulated gastrointestinal digestion in vitro: Charge properties of peptides affect digestive stability. Food Rev. Int. 2013, 52, 334-341. [CrossRef]

37. Wada, Y.; Bo, L. Effects of industrial heating processes of milk-based enteral formulas on site-specific protein modifications and their relationship to in vitro and in vivo protein digestibility. J. Agric. Food Chem. 2015, 62, 6787. [CrossRef]

(C) 2020 by the authors. Licensee MDPI, Basel, Switzerland. This article is an open access article distributed under the terms and conditions of the Creative Commons Attribution (CC BY) license (http://creativecommons.org/licenses/by/4.0/). 